\title{
Wielogłosowa szkoła obywatelskiego myślenia
}

Zacznijmy od słów, które otwierały zaproszenie na IV Kongres Dydaktyki Polonistycznej:

zadaniem uniwersytetu oraz szkoły jest urzeczywistnianie - może nazbyt idealistycznego, choć właśnie dlatego ważnego - przekonania o konieczności ulepszania świata, wprowadzania uczniów i studentów nie tylko w przestrzeń literatury, języka, sztuki, ale też w fundamentalne prawidłowości życia społecznego. Powszechnie znane jest zdanie Jana Zamoyskiego: „Takie będą Rzeczypospolite, jakie ich młodzieży chowanie...”. Warto jednak przytoczyć dalszy ciąg myśli zapisanej w roku $1600 \mathrm{w}$ akcie fundacyjnym Akademii Zamojskiej: „Nadto - pisał kanclerz wielki koronny i znamienity mąż stanu - przekonany jestem, że tylko edukacja publiczna zgodnych i dobrych robi obywateli".

Organizatorzy kongresu - Pracownia Innowacji Dydaktycznych Instytutu Filologii Polskiej Uniwersytetu im. Adama Mickiewicza we współpracy z Komisją Dydaktyczną Komitetu Nauk o Literaturze Polskiej Akademii Nauk - zaproponowali temat: „Lekcja POLSKI(ego) - praktyki edukacyjne wobec niepokojów XXI wieku”. Jego istotne znaczenie - co potwierdziło wielu uczestników sympozjum - wynikało z faktu, że żyjemy „w okresie, kiedy lekcje języka polskiego są i wciąż na nowo stają się lekcją Polski, autokrytyczną refleksją, niefundowaną na samoafirmującym się zbiorowym ego". Patronat honorowy nad wydarzeniem, które miało miejsce w dniach 20-23 listopada 2019 roku, w roku 100-lecia Uniwersytetu im. Adama Mickiewicza, objął Jego Magnificencja Rektor UAM prof. dr hab. Andrzej Lesicki, a patronat medialny - nasza redakcja.

W spotkaniach kongresowych wzięło udział ponad 350 osób z kraju i zagranicy. Dominowali przedstawiciele większości polskich uniwersytetów, byli też goście z uczelni spoza Polski, delegaci ODN-ów, nauczycielki i nauczyciele ze szkół z całej Polski, reprezentanci fundacji społecznych 
i czasopism. W erudycyjnych wykładach i 3 panelach plenarnych, w obradach prowadzonych w 24 sekcjach, spotkaniach autorskich i warsztatach edukacyjnych uczestniczyli także studenci i uczniowie ${ }^{1}$.

Obrady stały się okazją do wymiany uwag i pomysłów wyprowadzonych z rzeczywistej praktyki edukacyjnej ukierunkowanej na budowanie naszej wspólnej przyszłości. Były - jak słusznie od początku zakładali organizatorzy - wielogłosową szkołą obywatelskiego myślenia. Poruszane zagadnienia w pełni dowiodły słuszności decyzji dotyczącej wyboru głównego tematu IV Kongresu Dydaktyki Polonistycznej.

Bogaty program obrad skłaniał do namysłu nad perspektywami obecnej polonistyki i refleksji dotyczącej jej społecznych oddziaływań. Prezentowane w referatach zagadnienia i ożywione, wieloaspektowe dyskusje obejmowały zagadnienia związane z poszukiwaniem odpowiedzi między innymi na pytania: czym jest polskość, jak rozumieć tożsamość, inność, jaki powinien być kanon, jak tworzyć w szkole przestrzeń porozumienia między przedstawicielami różnych narodów, jak wprowadzać młodych ludzi w fundamentalne prawidłowości życia społecznego, jak pokazywać bogactwo i znaczenie różnic, które nie muszą dzielić, ale mogą siebie wzajemnie wspierać, jak wzmacniać podmiotowość i samodzielność uczniów oraz studentów, ale też co robić, by wszyscy uczestnicy szkolnego i akademickiego dialogu mogli być ludźmi w pełni wolnymi i twórczymi?

Wiele z ważnych kongresowych wystąpień ukaże się w tomie zbiorowym. Jego wydanie jest jednak sprawą czasochłonną i materiały opublikowane zostaną dopiero w przyszłym roku. Dlatego zdecydowaliśmy się zamieścić niektóre $\mathrm{z}$ wypowiedzi w dość obszernych fragmentach $\mathrm{w}$ obecnym numerze „Polonistyki. Innowacji”, licząc, że choć w części zobrazują niektóre z poruszanych tematów. Prezentujemy dwa dydaktyczne wykłady mistrzowskie, które wygłosili prof. Barbara Myrdzik oraz prof. Zenon Uryga. Każdy kolejny tekst zamieszczony w działach Teksty i konteksty oraz $W$ strone ucznia i studenta to artykuły przygotowane przez badaczki i badaczy z innej uczelni. Choć nie możemy w numerze pisma zaprezentować szkiców wszystkich uczestników kongresu, to jednak nie sposób pominąć tak ważnej grupy, jaką byli na kongresie szkolne polonistki i szkolni poloniści, stąd też i wypowiedź nauczycielki jest w numerze prezentowana.

Jesteśmy przekonane, że niniejszy numer niewątpliwie odpowiada potrzebie czasu. Pragniemy bardzo serdecznie podziękować wszystkim Autorom za teksty, a Szanownych Czytelników gorąco zapraszamy do lektury. Wyrażamy też nadzieję, że lektura poszczególnych rozważań przyniesie satysfakcję, bliską tej, jaka towarzyszyła uczestnikom IV Kongresu Dydaktyki Polonistycznej. Jedna z uczestniczek już po jego zakończeniu napisała:

${ }^{1}$ W poprzednim numerze zamieściliśmy obszerne sprawozdanie z kongresu - zob. „Polonistyka. Innowacje” 2019, nr 10, s. 173-179; a z pełnym opisem działań podjętych w Poznaniu można się zapoznać na stronie internetowej: http://kongresdydaktyki2019.pl 
Dni Kongresu były dla mnie ważnym czasem. Pozwoliły upewnić się, że nie jestem sama w tym edukacyjnym zawirowaniu, w które zostaliśmy wrzuceni. Spotkałam wielu mądrych ludzi, którzy przywrócili mi wiarę w sens tego, co robię w czasie moich spotkań z Uczniami, niezależnie od zmieniającej się władzy. Pozostanę również pod wrażeniem kultury wypowiedzi i uważności na drugiego człowieka podczas trwania Kongresu. Dziękuję za inspiracje, życzliwość i poczucie, że przynależę do wielkiej Polonistycznej Rodziny.

Oby takie dobre myśli towarzyszyły nam wszystkim jak najdłużej. Cieszymy się też na kolejne naukowo-dydaktyczne spotkanie w Gdańsku, na które zaproszenie - w imieniu jego organizatorów - przekazuje prof. Grażyna Tomaszewska, a nasza redakcja już dzisiaj oferuje patronat medialny nad tym ważnym sympozjum.

Anita Gis

Maria Kwiatkowska-Ratajczak 